\title{
Multiple sclerosis in research workers studying swayback in lambs: an updated report
}

\author{
G DEAN, EI MCDOUGALL, M ELIAN
}

SUMMARY Four out of seven research workers into swayback disease, a neurological disease of lambs, developed symptoms and signs of multiple sclerosis, and were reported in 1947. A further worker later joined the group. All of the original seven have died and two at necropsy had multiple areas of demyelination in the brain and spinal cord. The chance of four or more out of a random group of eight men developing multiple sclerosis is about one in a thousand million. Multiple sclerosis has not occurred in other workers on swayback disease elsewhere.

Innes (1939) summarised the work that he and his colleagues had done on swayback, a disease of the central nervous system affecting young lambs.' At about the same time he noted that three of his colleagues who were or had been taking part in the investigations had begun to complain of neurological symptoms. Campbell $e t a l^{2}$ gave details of what had, since 1946, become four out of the group with symptoms of disseminated or multiple sclerosis. ${ }^{2}$ These patients were further discussed by Lumsden, ${ }^{3}$ Campbell, ${ }^{4} \mathrm{McAlp}$ ine $e t \mathrm{al}^{5}$ and Symonds. ${ }^{6}$ The possibilities briefly considered were that such an unusual occurrence in a group linked by their work might be due to a common exposure to laboratory fumes and dust, or to each other, or to some incidental infectious sheep disease or that it might be related to the swayback disease that they were studying.

Swayback occurs in lambs from apparently healthy ewes. The signs appear either at birth (acute cases) or within a few weeks (mild or delayed cases). There is always ataxia, sometimes blindness. The disease takes a progressive non-febrile course with usually a fatal end, except in the mildest cases. Most affected lambs die as a result of their inability to follow and suckle their dam and the consequent inanition and secondary infections.

Address for reprint requests: Dr Geoffrey Dean, Director. The Medico-Social Research Board, 73, Lower Baggot Street, Dublin 2. Ireland.

Dr EI McDougall, Institute of Animal Pathology, Cambridge UK, (retired)

Dr M Elian, Regional Centre for Neurology and Neurosurgery, Oldchurch Hospital, Romford, Essex, UK.

Received 8 May 1984 and in revised form 17 December 1984. Accepted 24 December 1984
The lambs that are mildly affected show only microscopic pathological changes consisting of neuronal lesions in the red nucleus and demyelination in the spinal cord motor tract. More acute cases show, in addition, gross symmetrical cerebral demyelination of varying severity. Inflammatory cell infiltration and inclusion bodies are absent. ${ }^{7-13}$ Cancilla and Barlow consider that the primary change is in the axon in swayback with secondary change in the myelin. ${ }^{11}$

The disease occurred widely in the United Kingdom and a similar disease occurred in other sheeprearing countries. In some areas the disease was enzootic and a threat to sheep farming. Its incidence appeared irregular and sporadic. It was found that it could be prevented by administering copper to the ewes during pregnancy. Subsequent field and experimental studies have shown it to be a reproducible nutritional disorder. ${ }^{10-13}$

The research group in which the suspected cases of multiple sclerosis were reported were based in Cambridge and Derbyshire. Swayback or a similar disease was studied by other workers, some at Weybridge, ${ }^{14-16}$ Edinburgh $^{8 y^{17}}$ and Aberdeen, ${ }^{10}{ }^{1814}$ in the United Kingdom and some in Australia from the $1930 \mathrm{~s}^{2021}$ in New Zealand, ${ }^{22}$ in South Africa ${ }^{23}$ and in Peru. ${ }^{24}$

Those who worked in the Cambridge and Derbyshire group are now all dead or retired. We have traced their history, their exposure to swayback material and other information that might be relevant to the incidence of multiple sclerosis. We have also tried to obtain as far as possible comparable information from other groups who have worked on swayback. In making this report, we have considered only research workers and their technical assistants who themselves handled affected sheep or blood and tissues, such as liver, brain or spinal cord, 
Table 1 Summary of information about research workers on swayback in lambs in the Cambridge and Derbyshire group

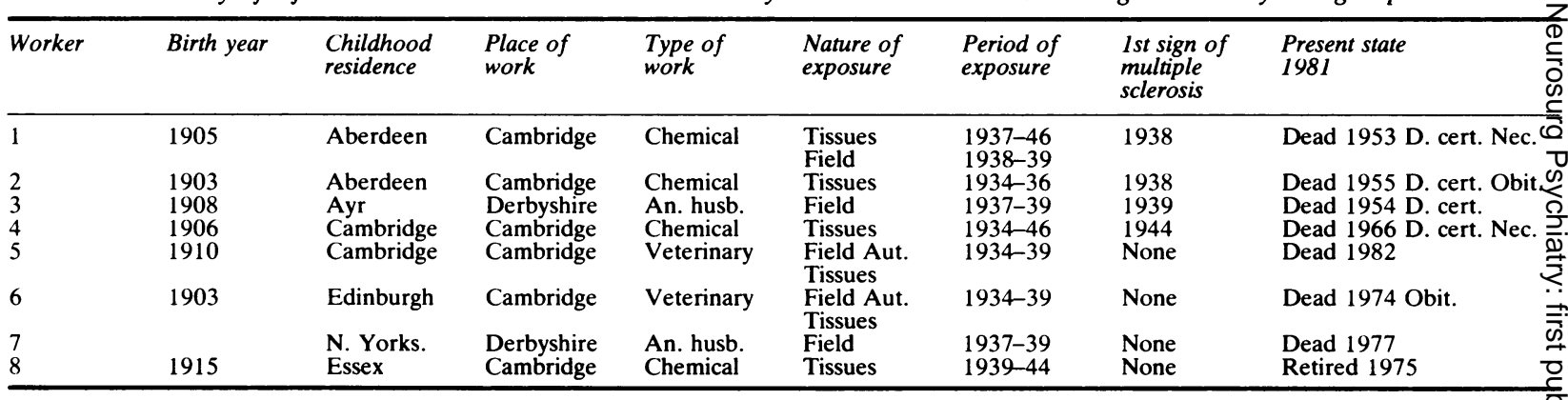

Workers 1-4 correspond to patients 1-4 in report by Campbell et al. ${ }^{2}$ Place of work refers to the swayback investigations. Type of work: An. husb. $\overline{\bar{D}}$ Animal husbandry (advisory work, field survey, field trials organisation). Nature of exposure: Tissues = preparing and examining blood and tissues from affected lambs. Field = handling the ewes and lambs in the field. Aut. = carrying out necropsies on affected lambs. Period of exposure is mainly from Campbell et al. ${ }^{2}$ Present state is followed bv D. cert. = death certificate or obit. = obituary as sources of information. Nec. = necropsy carried out. The obituaries consulted were: workers 1 and 2. Aberdeen University Review (1953-4) 35,325 and (1955-6) 36.329. Worker 6. J Pathol (1976) 119 187-191.

Table 2 Additional biographical information on the four cases of multiple sclerosis

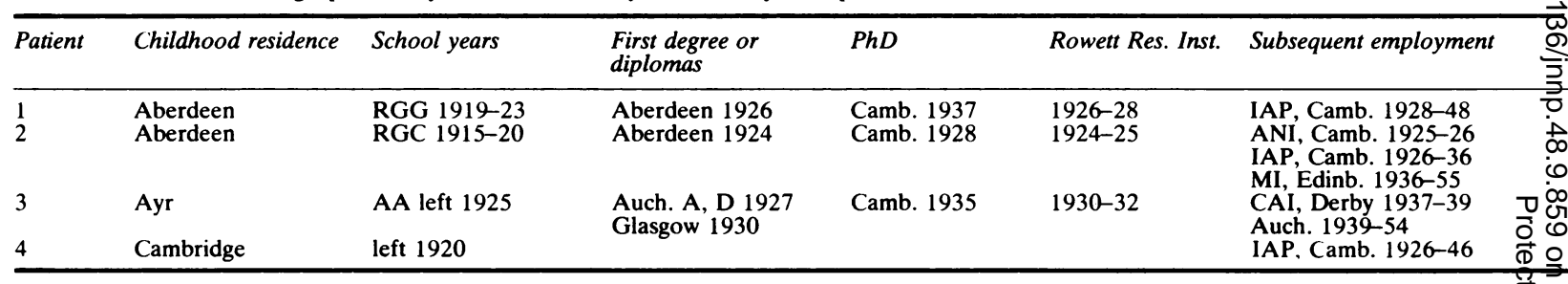

Schools, RGC $=$ Robert Gordon's College, Aberdeen, AA = Ayr Academy. Under diplomas and employment, Auch. = West of Scotland Colle Agriculture, Auchencruive and A and D = Diplomas in Agriculture and Dairying. The dissertations for PhD were in the Facultv of Agriculture and as follows: Patient 1 'Some observations on the chemistry and toxicology of buttercups (Ranunculus spp.) and bracken (Pteris aquilina). Patient $2 \cdot$ A 9 . of the effects of high protein diet on sheep.' Patient 3 'Ihe calcium, phosphorus and vitamın $U$ requirements of swine.' Patient 4 was a laboratory assistam from leaving school. In the period given under Rowett Research Institute, patient 3 spent his time between that Institute and the University in Aberdee Under subsequent employment, IÅP = Institute of Animal Pathology, ANI = Animal Nutrition Institute, in Cambridge and MI = Moredun Inst还 Edinburgh; CAI = County Agricultural Institute.

from affected animals or who carried out chemical, haematological or histopathological examinations on this material.

\section{Results}

\section{The Cambridge and Derbyshire Group}

The Cambridge and Derbyshire group comprised five people who worked at the Institute of Animal Pathology in Cambridge and two agricultural officers working in Derbyshire. One of the Cambridge workers left in 1936 and a new member (EI $\mathrm{McD}$ ) joined in the work there in 1939 and he has been included in this report as the eighth member of this group. The Cambridge workers were concerned with transmission studies, histopathological and chemical work in the years 1934-44. The Derbyshire workers carried out field trials on the use of copper, which had been shown to be deficient in the disease in Australia, in the form of salt licks for the prevention of swayback in 1937-38 and joined with the Cambridge workers in a more detailed study of the disease and the role of copper in its prevention in field trials on Bradwell Moor in North Derbyshire in 1938-39..$^{25-28}$ The information that we have gathered about the eight research workers in this group is summarised in tables 1 and 2 .

The four cases of multiple sclerosis

Necropsies were carried out on two of the four patients who had been diagnosed as having multiple sclerosis. In one, the demyelinating disease was of severe type, similar to Schilder's disease or to the effect on the brain of severe swayback in lambs and in the other it was typical of multiple sclerosis. The remaining two multiple sclerosis patients died after operation for duodenal ulcers and there was no necropsy. The medical histories of the four patients are given below. They are numbered to correspond with the earlier report by Campbell et al (1947). ${ }^{2}$

Worker 1 (Patient I)

In 1938, at the age of 33 years, while working on swayback material, he developed weakness in both legs which improved after a few months. The symptoms returned more severely in 1939 but he recovered the strength in his legs after about one month. In February 1940, after a relapse, he was admitted to Addenbrooke's Hospital, Cambridge. There was a further relapse six months later at which time he could not make manual manipulations, his 
gait was staggering and his speech was affected. He improved after four weeks in bed. He continued with numerous attacks and periodical impairment of vision in one or both eyes, with some remissions, until his admission to the Radcliffe Infirmary, Oxford, in 1947, under the care of Dr Ritchie Russell, by which time he was disorientated, mentally confused and incapable of sustained conversation. He was temperamentally aggressive but there was euphoria. He had slurring of speech, incoordination of his arms and legs, diminution of vibration sense in his legs, spasticity of all his limbs, the plantar responses were extensor, his knee and ankle tendon reflexes were brisk and the abdominal reflexes were absent. He also had a pleural effusion following a previous haemothorax resulting from a fall. He gave his age as 32 when he was, in fact, 42. Efforts to help him walk with a walking aid were not successful. Copper estimations were undertaken and they indicated a low excretion of copper. The WR was negative and the Lange gold curve was 34444310 . There was no increase in CSF cells or protein. He was admitted to Morningfield Hospital in Aberdeen in July, 1951 with " inability to walk without staggering, incontinence of urine and generally unable to do things". He was mentally confused. There was no nystagmus but he had "a constant static tremor". He was very childish and aggressive, otherwise the examination was the same as in 1947.

He died at Morningfield Hospital on the 11 November, 1953, aged 48 and necropsy was undertaken by Dr HG Richmond. His body was wasted and he had a deep excavating bedsore. On opening the skull there was an increase in subarachnoid fluid of gelatinous character over both cerebral hemispheres, the total weight of the brain was $1,150 \mathrm{~g}$, there was obvious atrophy of the gyri, with widening of the sulci in all lobes of the brain, possibly more marked in the frontal and pyramidal regions. Incision into the lateral ventricles showed clear cerebrospinal fluid, the arteries at the base of the skull were normal and the pituitary gland was normal in size. The brain and spinal cord, a number of posterior root ganglia and the left Gasserian ganglion were removed and sent to Dr Charles Lumsden, who at that time was at Maida Vale Hospital, London. His death was certified as due to encephalomyelitis.

Professor Lumsden died in 1974 and, unfortunately, in spite of an intensive search no records can be found of this necropsy at Maida Vale Hospital, at Professor Lumsden's department of pathology at Leeds or at his home. No report was sent to Professor Young, Professor of Pathology at Aberdeen nor to Dr Richmond who did the necropsy, nor does Professor Lumsden's widow have any relevant records. Fortunately, Professor Lumsden wrote to $\mathrm{Dr}$ AMG Campbell from Maida Vale about the necropsy in May 1957. In the letter he said: “Though I would not say very much about it meantime until it has been fixed more thoroughly, examined and processed for celloidin sections, etc there is no doubt there are extensive foci of demyelination in the cerebrum. As far as I could tell, the cerebellum was negative as well as mid-brain and medulla. The cord has only been cut so far at three levels and I think there is rather a lot of secondary degeneriation. Certainly, the lesion in the cerebrum is complicated by atrophy which may account for the relatively poor demarcation of the demyelination".
A report by Professor Lumsden was published about this patient's necropsy in $1958 .^{3}$ In it he says " Since relation between 'swayback' and human disease is implied in this discussion, I shall begin by referring to the report of Campbell et al (1947) ${ }^{2}$ which has naturally received prominence in the world literature on demyelinating disease. It will be remembered that four out of seven research workers on swayback were thought to be affected by a disease indistinguishable from multiple sclerosis. Since over 10 years have now elapsed, ample time would seem to have occurred for re-assessment of this report. In this instance, some fresh information would seem to be a paramount need. The clinically most typical case of the four was the only one known to me; this patient eventually succumbed to multiple sclerosis which, I think by a curious coincidence only, happened to be of a rather "transitional" type with diffuse cerebral demyelination and with plaques of the more typical discrete type only in the optic pathway, cerebellum, brain-stem and cord. I hope to report and illustrate the pathological findings in this case elsewhere in full detail. As far as I can ascertain, this case was purely coincidental and has no relevance whatsoever to the swayback problem. If we were to learn that the diagnosis of multiple sclerosis is no longer tenable in the remaining cases cited in the 1947 report, I think it would be of real value in the difficult field of multiple sclerosis research". Professor Lumsden reported to Professor Young that the necropsy findings were "very similar to that of Schilder's disease".

\section{Worker 2 (Patient 2)}

In June 1938, at the age of 35 years, for a period of two days this worker complained of a peculiar sensation in his legs and found walking an effort and could not chase the ball at tennis. This cleared up but later in the same year there was weakness in both legs, the right leg was more affected than the left. The third, fourth and fifth fingers of the right hand also felt numb. On examination in December 1938, his legs had recovered but his fingers were still numb and this was affecting his writing. There were no other abnormal symptoms. There was marked loss of two point discrimination in the third, fourth and fifth fingers of his right hand. There was no weakness or ataxia. The tendon reflexes were equal and brisk. The abdominal reflexes were brisk and the plantar reflexes were flexor, the optic discs were normal and there was no nystagmus, the Wasserman reaction was negative. In 1939, he complained of blurring of vision, which was diagnosed as retrobulbar neuritis, affecting both eyes. His vision recovered in about six weeks. Since then he had been well except for occasional numbness in the right leg and symptoms due to peptic ulcer. He died following an operation for duodenal ulcer at the age of 52 at Edinburgh in December, 1955. No necropsy was undertaken.

The report by Campell et al $(1947)^{2}$ states that his sister "had died from disseminated sclerosis". None of the other members of the family can now remember her having disseminated sclerosis but rather tuberculosis. She died in 1927 aged 29 years and the diagnosis on her death certificate is "pulmonary tuberculosis". So far no evidence except for the statement in the 1947 paper can be found that she-alse had disseminated sclerosis. 
Although this research worker's symptoms were never very severe, the story of weakness in his legs in 1938, of numbness in his fingers affecting his writing and of retrobulbar neuritis in 1939 and then of minor attacks of paraesthesia after this time makes the diagnosis of probable multiple sclerosis acceptable.

\section{Worker 3 (Patient 3)}

In August 1939, at the age of 31, while still in Derbyshire this patient complained of slight weakness in the right leg and a change of sensation in the left leg. On examination his tendon reflexes were exaggerated and the right plantar response was extensor. There was difficulty in eliciting the abdominal reflexes. He recovered but in 1945 he complained of haziness in the vision of his left eye and he was seen by an ophthalmologist who diagnosed retrobulbar neuritis and considered it was due to disseminated sclerosis. On examination in 1945 , the plantar responses were then flexor on both sides. The abdominal reflexes could not be obtained. There was a slight shakiness of the right eye on looking to the right but no sustained nystagmus. There was pallor of the temporal half of the left disc which had not been present when he was seen previously by the same physician in 1939 . In view of his history, the eye symptoms and signs, the extensor plantar response in the right leg in 1939 and the absence of abdominal reflexes in 1945 , it was considered that he was suffering from disseminated sclerosis. His brother still remembers that in 1939 he was in bed for three weeks with weakness in his legs and that eye symptoms diagnosed as retrobulbar neuritis, developed while he was living in Ayr. His brother also remembers how he used to walk with a swaying gait and that he could not walk in a straight line.

In 1947, he fell from the platform of a bus in Ayr and injured his head but he was conscious on admission to hospital. His widow reports that his walking slowly deteriorated after this so that he had to retire in December, 1953. During the last two years of his life his walking deteriorated more rapidly, although he could still walk unaided. His widow reports that there was mental deterioration in the last year of his life. He died at Ayr Hospital at the age of 46 years in 1954 after an operation for a perforated duodenal ulcer. No necropsy was undertaken. Probable multiple sclerosis would appear to have been the correct diagnosis.

\section{Worker 4 (Patient 4)}

In 1945 , at the age of 39 years, this patient noticed that his left leg was inclined to drag. This lasted for a few days and then it completely recovered. In 1946, he noticed that he was dragging his right leg and his walking was unsteady. This also improved and when he was examined by a neurologist there was no obvious weakness in his limbs but his knee and ankle tendon reflexes were exaggerated, more so on the left where there was also ankle clonus. Both plantar responses were extensor. Although there was no gross weakness or ataxia, attempts to hop indicated some weakness and loss of balance, particularly on the left. The abdominal reflexes could be obtained. In 1950, he was thoroughly investigated at the National Hospital, London, by a number of neurologists, including Dr Elkington, Sir Charles Symonds, Sir Francis Walshe and Dr MacDonald
Critchley. The first three considered that he had disseminated sclerosis and Dr Critchley though it was human swayback. At this time his legs were weak and spastic with clonus of both knees and ankles, the abdominal reflexes were absent, the plantar responses were extensor. The cranial nerves were normal. A psychological report showed signs of slight but definite organic intellectual impairment with difficulty in retention and learning. During 1950, he had periodic blurring of vision and difficulty in maintaining an erection. By 1953, his vision had become very poor so he could only read the headlines in the newspaper. In 1952 his WR was positive and he had an abnormal Lange gold curve (5543222100). The CSF cells were slightly increased with a weakly positive CSF globulin test.

He died in December 1966, at the age of 60 and had a full necropsy at Addenbrooke's Hospital. His brain weighed $1,215 \mathrm{~g}$, there was clear differentiation between the grey and the white matter of the brain. Scattered in the brain substance there were firm pink plaques, principally around the ventricles, the spinal cord surface showed similar plaques or pink areas of irregular lengths. There was moderate symmetrical dilation of the ventricles and some of the cerebral plaques were $2 \times 1 \mathrm{~cm}$, in cross section Cortical and subcortical plaques were not conspicuous There was generalised reduction of the white matter and thinning of the corpus callosum. The medulla ribbon was slightly thinner than normal for the patient's age, the cerebellum contained only one or two small grey patches up to $1 \mathrm{~mm}$ in diameter in the white matter. In the medulla there were two gelatinous grey areas lateral to the hypoglossa $\vec{D}$ nuclei, the pons showed a grey patch in the left brachium $\infty$ conjunctivum and a similar less well defined area on the right. The spinal dura was normal. Scattered throughouf the length of the cord were numerous grey patches if haphazard distribution. These were most numerous and extensive in the cervical cord but the thoracic and lumbap cord were also affected. In one mid-thoracic section almost the entire cut section was involved. Microscopically, the brain and cord showed a number of plaques of gliosis with some perivascular round cell infiltration. Special stains showed lipid accumulation and loss of myelin in these areas (Dr Peter R Millard).

In 1981, the slides were re-examined by Professor Ingrid Allen of Queen's University, Belfast, who reported: "Sections have been studied from grey matter, deep white matter, basal ganglia, pons, medulla, cerebellum and spinal cord. In all the sections studied there are discrete areas of demyelination of some duration. The meninges are not inflamed. There is no abnormality of the cortical grey matter. In the white matter there is very diffuse gliosis, marked perivascular inflammation which, outside the areas of demyelination, consists largely of a lymphocytic reaction. The areas of demyelination are relatively discrete and are surrounded by intense glial reaction. Within the demyelinated areas astrocytes are present, blood vessels are thickened and there is a mixed perivascular inflammatory reaction. Some of the most striking areas of demyelination are adjacent to the ventricles. Sections from the pons, medulla and cerebullum show similar lesions. Sections from the spinal cord show very marked demyelination with the presence of neutral fat. Overall, the picture is that of an inflammatory demyelinating disease. The histology is quite 


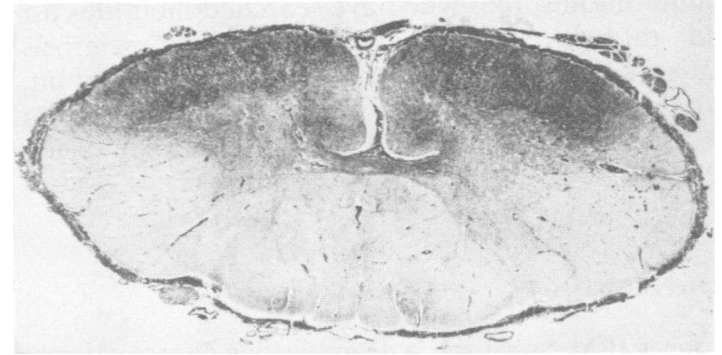

Fig 1 Spinal cord demyelination (Haematoxylun and Eosin. $\times$ 9.5.) (Patient 4)

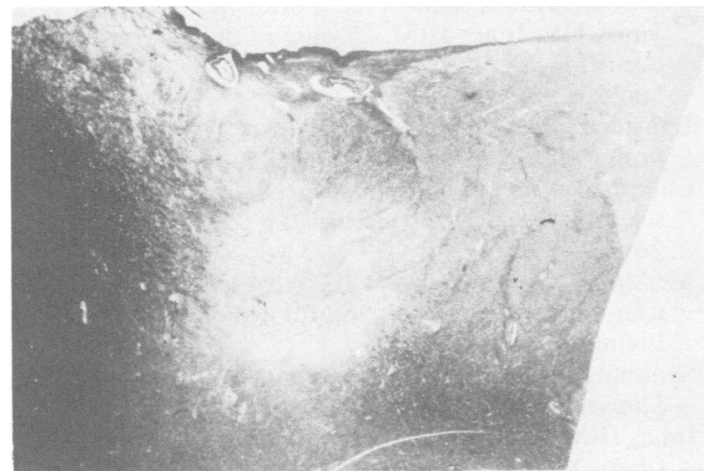

Fig 2 Plaque in brain. (Luxol fast blue/Haematoxylin and Eosin. $\times$ 7.5.) (Patient 4)

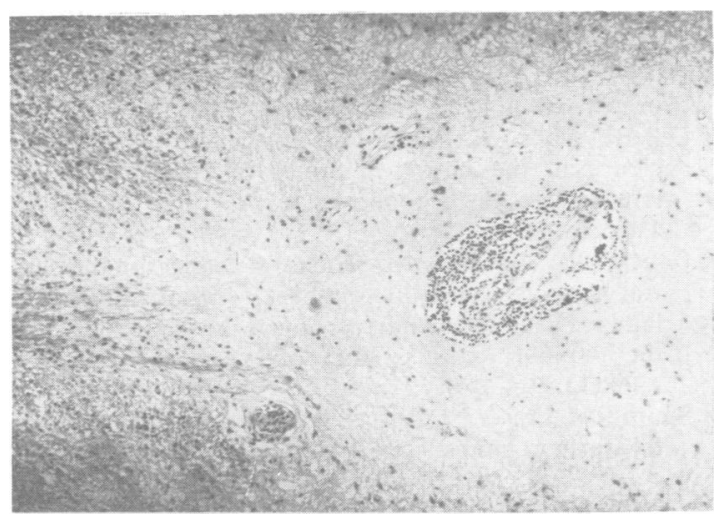

Fig 3 Deep white matter. (Luxol fast blue/Haematoxylin and Eosin. $\times$ 240.) (Patient 4)

compatible with some form of multiple sclerosis."

With this history and the clinical and the necropsy findings, the undoubted diagnosis is multiple sclerosis. When he died, Dr Millard of Cambridge sent part of the brain to Dr PA Palsson of the Institute of Experimental Pathology, University of Iceland, Reykjavik. A preparation was injected into five sheep intracerebrally in 1967 to see if it would induce scrapie. The last of the sheep were killed in 1979 and examined. No sign or evidence of scrapie was found (Personal communication 1982).

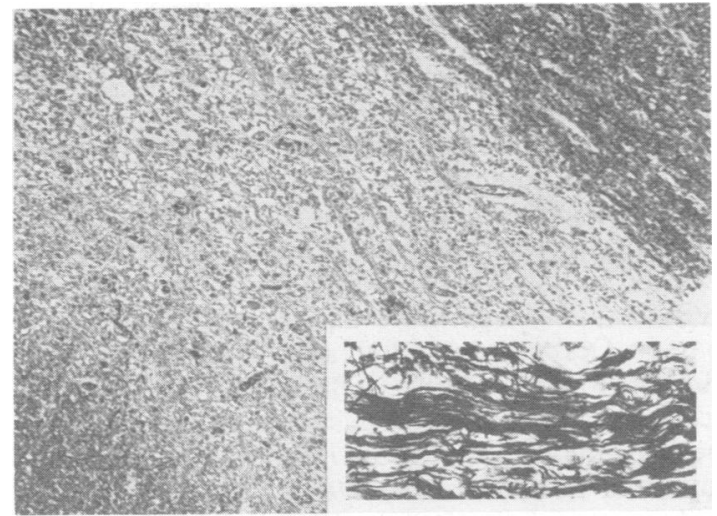

Fig 4 Pons. (Luxol fast blue/Haematoxylin and Eosin. $\times$ 100.) (Patient 4)

Inset: Axis cylinder stain. (Palmgren. $\times$ 600.)

Other groups who have worked on swayback

Information was obtained by correspondence about research workers in other groups concerned with the study of swayback. Twelve of these were at Weybridge, eight in Edinburgh, five in Aberdeen, nineteen in Australia and New Zealand and six in South Africa. The Weybridge group carried out much of their field work on sheep from the same area of Derbyshire as the Cambridge and Derbyshire group had carried out their field trials. All groups contained members who had handled fresh brain material. None of the fifty workers in these other groups has shown signs of multiple sclerosis; only one showed a neurological disease (motor neuron disease).

\section{Discussion}

It is difficult to find a common cause that could apply to all four cases of multiple sclerosis as well as not applying to those who did not develop the disease. As gangue from old lead mines is common on Bradwell Moor ${ }^{31}$ where the Derbyshire field trials were carried out, it is possible that there could have been short exposure to lead containing dust in the laboratory from the drying and powdering of samples of tissue or pasture. Symonds suggested that they might have been exposed to basic encephalitogenic protein. ${ }^{62430}$ The possibility of a relation between the human and sheep diseases has been tested by intracerebral injection of material from cases of multiple sclerosis into sheep..$^{32-34}$ Although some cases of scrapie were reported at first, it has not proved possible to confirm this and tests by Pálsson with the brain of patient 4 failed to produce scrapie. Visna, which occurred naturally in Iceland until 1965, has not been reported in the United Kingdom.

The occurrence of four cases of multiple sclerosis 
or a multiple sclerosis-like illness in the Cambridge and Derbyshire group and the similarity of the symptoms and necropsy findings of one of them to Schilder's disease and the anatomical similarity of the latter to acute swayback disease might suggest a relation between the two diseases. However, a similarity need not imply a causal relation. The absence of multiple sclerosis in the survey of fifty other workers on swayback, twelve of whom were concerned at a later period with material from the same part of Derbyshire as the earlier workers, gives no support to any strong correlation between multiple sclerosis and working on swayback disease. It is perhaps relevant that the symptoms in workers 1,2 and 3 all started in 1938-39.

Two out of the four multiple sclerosis patients, those who developed multiple sclerosis in $1938 / 39$, originated from the Grampian area of north-east Scotland where there is a higher prevalence of multiple sclerosis than in England and Wales and where the multiple sclerosis prevalence in middle-aged men, 35-44 years, is $200(200 \cdot 4)$ per 100,000 , or 1 in 500. (Phadke, JG and Downie AW. Personal communication). Using this high prevalence rate the Binomial Probability Distribution shows that the chance of four or more out of a random group of eight men having multiple sclerosis is about 1 in $10^{4}$, or 1 in a thousand million. The only linking factor that has been ascertained is that this group of eight veterinary research workers were working together with the brains of lambs that had a disease of the central nervous system.

It is concluded from a review of the history and necropsy findings that four out of eight, not seven, veterinary research workers into a disease of the CNS in lambs, swayback disease, developed multiple sclerosis or a multiple sclerosis-like illness. This strange happening is very unlikely to be coincidental and, with the reported epidemic of multiple sclerosis in the Faroe Islands after World War $2^{35}$ supports the concept that there is a major environmental factor, probably an infective factor, in multiple sclerosis. It remains an important clue to the cause of the disease.

We are indebted to the numerous former workers on swayback, to their colleagues and relatives in the United Kingdom, Australia, New Zealand and South Africa, who helped us with this research. We also thank Mr JP Brophy, Regional Administrative Office, Perth, for his help in tracing what happened to workers on swayback disease in Australia. Dr CS Treip, consultant neuropathologist, Addenbrooke's Hospital, Cambridge, provided pathology reports, blocks and slides about the necropsy on patient 4 . We also thank the doctors and records staff of numerous hospitals who have searched their files for old records about the four multiple sclerosis patients. Mr AV Vincent, Trinity College, Dublin, provided statistical advice. Miss Hilda McCoughlin assisted with the study and in the preparation of the report.

\section{References}

' Innes JRM. Swayback: a demyelinating disease of lambs with affinities to Schilder's encephalitis and its prevention by copper. J Neurol Psychiatry 1939;2:323-34.

${ }^{2}$ Campbell AMG, Daniel P, Porter RJ, Russell WR, Smith HV, Innes JRM. Disease of the nervous system occurring among research workers on swayback in lambs. Brain 1947;70:50-8.

${ }^{3}$ Lumsden CE. Demyelinating disease: The present situation. Proc $R$ Soc Med 1958;51:753-4.

${ }^{4}$ Campbell AMG. Veterinary workers and disseminated sclerosis. J Neurol Neurosurg Psychiatry 1963; 26: 514-5.

scAlpine D, Lumsden CE, Acheson ED. Multiple sclerosis: a Reappraisal. 2nd Ed. Edinburgh. Churchill Livingstone. 1972.

- Symonds CP. Multiple sclerosis and the swayback story ${ }_{7}$ Lancet 1975; 1:155-6.

' Innes JRM, Saunders LZ. Comparative Neuropathology Chap. XIV, London, Academic Press. 1962.

${ }^{8}$ Barlow RM, Purvis D, Butler EJ, McIntyre IJ. Swayback $\overrightarrow{\mathbb{D}}$ in south-east Scotland. i. Field aspects. ii. Clinicalo $\mathbb{D}$ pathological and biochemical aspects. J Comp Patho 1960; 70:396-410, 411-27.

' Barlow RM. Further observations on swayback. Transis tional pathology. J Comp Pathol 1963;73:51-60.

${ }^{10}$ Fell BF, Mills CF, Boyne R. Cytochrome oxidase defi ciency in the motor neurones of copper deficient of lambs; a histochemical study. Res Vet Sci 1965;6:170-1.

"Cancilla PA, Barlow RM. Structural changes in the central nervous system in swayback (enzootic ataxia) of lambs. IV. Electron microscopy of the white matter of the spinal cord. Acta Neuropathol (Berl.), 1968;11:294-300.

12 Smith RM, Fraser FJ, Russell GR, Robertson JS. Enzootic ataxia in lambs: appearance of lesions in the spinal cord during foetal development. J Comp Pathol 1977;87:119-28.

${ }^{13}$ Smith RM, Fraser FJ, Robertson JS. Enzootic ataxia in lambs: Absence of detectable neuronal pathology in foetal and neonatal spinal cord. J Comp Pathol 1978;88:401-8.

14 Hunter AH, Eden A, Green HH. Contributions to the study of swayback in lambs. i. Field experiments. $J$ Comp Pathol Ther 1945;55:19-28.

is Eden A, Hunter H, Green HH. Contributions to the study of swayback in lambs. ii. Blood copper.J Comp Pathol Ther 1945;55:29-40.

${ }^{16}$ Allcroft R, Clegg FG, Uvarov O. Prevention of swayback in lambs. Vet Rec 1959;71:884-9.

${ }^{17}$ Butler EJ, Barlow RM. Copper deficiency in relation to 
swayback in lambs. 1. Effect of molybdate and sulphate supplement during pregnancy. J Comp Pathol 1963;73:208-13.

${ }^{18}$ Mills CF, Fell BF. Demyelination in lambs born of ewes maintained on high intakes of sulphate and molybdate. Nature 1960;185:20-2.

"Mills CF, Williams RB. Copper concentration and cytrochrome oxidase and ribonuclease activities in the brains of copper deficient lambs. Biochem $J$ 1962;85:629-32.

${ }^{20}$ Bennetts HW, Beck AB. Enzootic ataxia and copper deficiency of sheep in Western Australia. Bull Council for Scientific Industrial Research 1942;147:1-52.

${ }^{21}$ McDonald IW. Enzootic ataxia of lambs in South Australia. Aust Vet J 1942;18:165-72.

${ }^{22}$ Cunningham IJ. Copper deficiency in cattle and sheep in peat lands. NZ J Sci Technol 1946;27:381-96.

${ }^{23}$ Schulz KCA, van der Merwe PK, van Rensburg P, Swart JS. Studies in demyelinating diseases of sheep associated with copper deficiency. Onderstepoort $J$ Vet Res 1951;25:35-7.

${ }^{24}$ Tabusso ME. Vida Agricola (Lima), 1941-2, 18, 719 $27,789-94,875-84,943-9$ and 19, 123-6 (Quoted in ref. 7).

${ }^{25}$ Dunlop G, Wells HE. "Warfa” (swayback) in lambs in North Derbyshire and its prevention by adding copper supplements to the diet of the ewes during gestation. Vet Rec 1938;1175-82.

${ }^{26}$ Dunlop G, Innes JRM, Shearer GD, Wells HE. Swayback studies in North Deryshire. J Comp Pathol
Ther 1939;52:259-65.

${ }^{27}$ Innes JRM, Shearer GD. Swayback: A demyelinating disease of lambs with affinities to Schilder's encephalitis in man. J Comp Pathol Ther 1940;53:141.

${ }^{28}$ Shearer GD, Innes JRM, McDougall EI. Swayback studies in North Derbyshire. ii. The relationship of the storage of copper and lead in the body tissues to the causation of swayback. Vet $J$ 1941;96:309-22.

${ }^{24}$ Carnegie PR, Lumsden CE. Encephalitogenic peptides from spinal cord. Nature 1966;209: 1354.

${ }^{30}$ Carnegie PR. Properties, structure and possible neuroceptor role of the encephalitogenic protein of human brain. Nature 1971;229:25.

${ }^{31}$ Ford TD, Rieuwerts JH. Lead Mining in the Peak District. Peak Park Joint Planning Board, Bakewell, Derbyshire. 1975.

${ }^{32}$ Sutherland JM, Wilson DR, Disseminated sclerosis in man and experimentation with sheep. Glasgow Med J 1951;32:302-10.

${ }^{33}$ Palsson PA, Pattison IH, Field EJ. Slow, latent and temperate virus infections. NINDB Mono. No. 2, pp. 49-54, Washington Public Health Service, Publication No. 1378. 1965 .

${ }^{34}$ Dick G, McAlister JJ, McKeown F, Campbell AMG. Multiple sclerosis and scrapie. J Neurol Neurosurg Psychiatry 1965;28:560-2.

${ }^{35}$ Kirtzke JF, Hyllested K. Multiple sclerosis in the Faroe Islands. 1. Clinical and epidemiological features. Ann Neurol 1978;5:6-21. 